\title{
Byssinosis in a textile factory in Cameroon: a preliminary study
}

\author{
J TAKAM, B NEMERY* \\ From the Unité de toxicologie industrielle et médecine du travail, UC Louvain, B-1200, Brussels, Belgium
}

ABSTRACT To assess the risk of byssinosis in a cotton textile factory in Cameroon a preliminary study was conducted on a random sample of 125 men from production areas and 68 men from nonproduction areas. Symptoms were assessed by a questionnaire, which also included questions regarding sleep; peak expiratory flow rate (PEF) was measured with a miniature peak flow meter at the end of a working day and total dust concentrations were assessed by static and personal sampling with Casella dust samplers giving values of $6.4 \pm 2.6 \mathrm{mg} / \mathrm{m}^{3}(\mathrm{~m} \pm \mathrm{SD})$ in production areas and $1.7 \pm$ $0.7 \mathrm{mg} / \mathrm{m}^{3}$ in control areas. Exposed subjects had significantly more symptoms (particularly in smokers) and lower PEF values than controls $(408 \pm 96 \mathrm{l} / \mathrm{min} v 468 \pm 70 \mathrm{l} / \mathrm{min}, \mathrm{p}<0.001)$. Twenty three exposed subjects (18\%) reported chest tightness on returning to work after the weekly break (compared with one control, p $<0.01$ ). Subjects with byssinosis had lower PEF values than those without chest tightness $(356 \pm 50 \mathrm{l} / \mathrm{min} v 426 \pm 951 / \mathrm{min}, \mathrm{p}<0.01)$, more chronic bronchitis $(52 \% v$ $6 \%, \mathrm{p}<0.001)$, they were more often smokers $(61 \% v 31 \%, \mathrm{p}<0.05)$, and came generally, though not exclusively, from the opening carding spinning department with the highest concentrations of total dust $\left(8 \pm 2 \mathrm{mg} / \mathrm{m}^{3}\right)$ and an estimated prevalence of byssinosis of $28 \%$. There were no significant differences in sleep related symptoms between the exposed and controls, though the 23 subjects with byssinosis tended to report more snoring (48\%), early morning headache $(48 \%)$, and sleep improvement over the working week $(44 \%)$ than all the other subjects $(28 \%, 24 \%$, and $24 \%$ respectively, $\mathrm{p}<0 \cdot 1)$.

Byssinosis is an occupational respiratory disorder in cotton, flax, and soft hemp workers. It is characterised by chest tightness and breathlessness at work after the week end break and may lead after several years of exposure to permanent respiratory impairment. ${ }^{12}$ The exact pathogenesis is unknown but endotoxins from bacteria contaminating the cotton are thought to be central in causing bronchial obstruction. ${ }^{34}$

The cotton textile industry is an important economic sector in many developing countries, including those in tropical Africa, where few investigations of occupational health have so far been published. We present here the results of a preliminary investigation in a cotton textile plant in Cameroon, a country of about 10 million inhabitants in Central Africa.

Accepted 19 October 1987

*Present address and requests for reprints to: Arbeids-en Verzekeringsgeneeskunde KU Leuven, Provisorium 1, Minderbroedersstraat 17 B-3000 Leuven, Belgium.

Presented at the annual meeting of the European Society for Clinical Respiratory Physiology (SEPCR) in Antwerp, Belgium, 22-26 June 1987.

\section{Study population, material, and methods}

The cotton plant studied is in the north of Cameroon and started operating in 1965. The plant, which is one of the most important textile plants in Central Africa, employs about 1200 men in the various processes from the opening of cotton bales up to the weaving. Further processing occurs at another location. A medical officer holds a clinic in the plant, but his activities are geared towards general medical problems rather than occupational health.

For this study, conducted by JT from 15 August to 10 September 1986, 206 blue collar workers were randomly selected from the payroll. Participation was not compulsory but few subjects declined $(n=6)$ or were unable to take part ( $\mathrm{n}=7$, six on holiday, one ill); thus 125 workers directly engaged in handling cotton were examined as were 68 workers from non-production departments, which included the laboratory and maintenance departments and watchmen. The former group comprised exposed workers and the latter control workers.

For assessing total dust concentrations 20 station- 
ary (at a height of $1.50 \mathrm{~m}$ ) and six personal air samplings were carried out in various areas of the plant by means of a battery powered Casella T13051/2 pump, at a sampling rate of $2 \cdot 24 \mathrm{1} / \mathrm{min}$ for about four hours. Millipore PTFE $5 \mu \mathrm{m}$ filters were weighed before and after the survey on a $0.01 \mathrm{mg}$ precision balance. On return from the survey, the weight of four unused filters had increased by $0.10( \pm 0.03) \mathrm{mg}$ and this value was subtracted from the final weights for calculating dust concentrations. No qualitative evaluation was made of the collected dust. Figure 1 shows the total dust concentrations found in the plant.

All subjects were examined at the end of their working day on any weekday. (Production in this plant is continuous and workers work six days a week, with their first working day not necessarily being a Monday.) No particular sequence was followed for examining exposed or control workers. Height and weight were measured and a questionnaire was administered, which included administrative data, questions on respiratory symptoms (cough, phlegm, dyspnoea, wheezing, and chest tightness) with their time course during the week, sleep related symptoms (see results), smoking and drinking habits, and past illnesses and occupational history.

The questionnaire was administered in one of the country's languages, with the help of an assistant for
Table 1 Anthropometric characteristics and smoking habits

\begin{tabular}{|c|c|c|}
\hline & $\begin{array}{l}\text { Control } \\
(n=68)\end{array}$ & $\begin{array}{l}\text { Exposed } \\
(n=125)\end{array}$ \\
\hline $\begin{array}{l}\text { Age (y) } \\
\text { Height (cm) } \\
\text { Weight (kg) }\end{array}$ & $\begin{aligned} 33.5 & \pm 6.8 \dagger \\
171 & \pm 5 \\
68.2 & \pm 6.4\end{aligned}$ & $\begin{array}{c}33 \cdot 5 \pm 5 \cdot 2 \\
171 \pm 6 \\
66.0 \pm 7 \cdot 5 * \\
(\mathrm{n}=115)\end{array}$ \\
\hline $\begin{array}{l}\text { Employment duration } \\
\text { (y) } \\
\text { Non-smokers } \\
\text { Ex-smokers } \\
\text { Smokers } \\
\text { Pack years }\end{array}$ & $\begin{array}{c}9 \cdot 9 \pm 3 \cdot 7 \\
40(58 \cdot 8 \%) \\
3(4 \cdot 4 \%) \\
25(36 \cdot 8 \%) \\
12 \pm 7 \\
(\mathrm{n}=28)\end{array}$ & $\begin{array}{c}11 \cdot 3 \pm 4 \cdot 4^{*} \\
77(61 \cdot 6 \%) \\
7(5 \cdot 6 \%) \\
41(32 \cdot 8 \%) \\
11 \quad \pm 8 \\
(\mathrm{n}=48)\end{array}$ \\
\hline
\end{tabular}

$* \mathrm{p}<0.05$.

+Mean \pm standard deviation.

translation when necessary. The subjects also performed at least three forced expiratory manoeuvres in a miniature peak flow meter (Peak Flow Monitor, Vitalograph) and the highest value of peak expiratory flow (PEF) was retained. Not all subjects had satisfactory lung function measurements, the most frequent problem being spuriously high values with the piston going to the end of the scale as a result of a forceful "spitting" effect. This problem with miniature flow devices has been recently reported by others ${ }^{5}$ and may be obviated by having the subject insert the mouth-

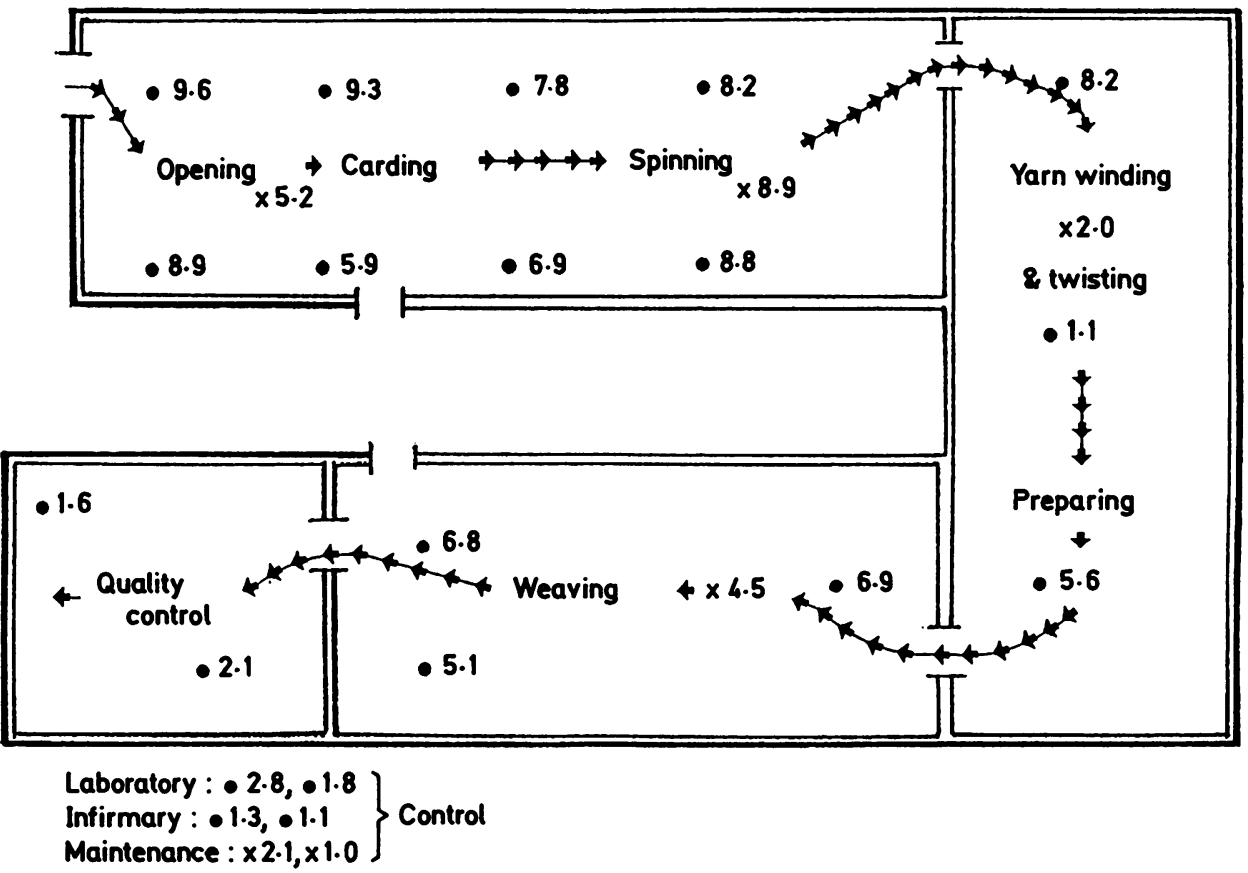

Fig 1 Schematic layout of plant with total dust concentrations (in $\mathrm{mg} / \mathrm{m}^{3}$ ) obtained by static ( $\bullet$ ) or individual ( $\times$ ) sampling. Arrows indicate flow of cotton. 

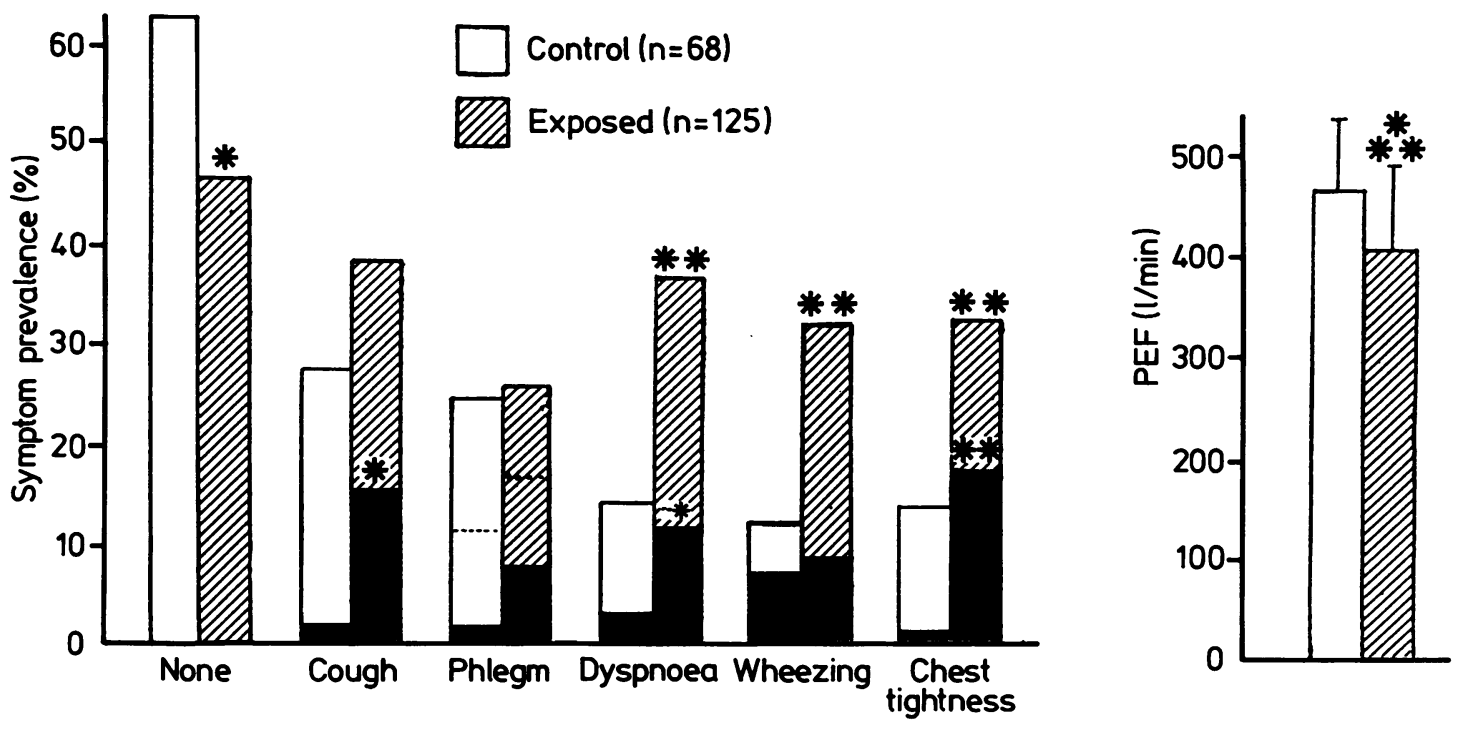

Specially first day of week

Fig 2 Symptom prevalences and PEF values (mean $\pm S D$ ) in control and exposed subjects. Interrupted lines in "phlegm" bars indicate prevalence of chronic bronchitis. For $P E F, n=53$ in control subjects and $n=101$ in exposed subjects.

$\sim^{*} p \approx 0.05, * p<0.05, * * p<0.01, * * * p<0.001$ for exposed $v$ control.

piece fairly deep into the mouth rather than around the lips only.

Data were analysed by chi-squared test with Yates's correction for comparing prevalences and Student's $t$ test or one way analysis of variance followed by testing contrasts for comparing means of continuous data.

\section{Results}

Exposed and control subjects were comparable with regard to age, height, and smoking habits (table 1). Exposed subjects weighed less $(-2 \cdot 2 \mathrm{~kg}$ ) and had been employed slightly longer $(+1.4 \mathrm{y})$ than control subjects. Because the numbers of ex-smokers were small, ex-smokers were included in the smokers category in the further analysis.

Figure 2 shows that more subjects reported respiratory symptoms in the exposed $(54 \%)$ than in the control group (37\%). Dyspnoea (when hurrying on level ground), wheezing, and chest tightness were significantly more prevalent in exposed subjects (33$38 \%$ ) than in controls (13-15\%). More exposed subjects reported their cough, dyspnoea, and chest tightness to be worse on the first one or two days of the working week $(12-18 \% v 1.5-2.9 \%)$. There was no significant difference in the prevalence of chronic bronchitis, defined as phlegm more than three months a year for at least two years (18\% among exposed and $12 \%$ among controls). There was a highly significant (p < 0.0001) difference of $60 \mathrm{l} / \mathrm{min}$ in PEF between control and exposed subjects.

Differences in symptom prevalences between control and exposed subjects were more pronounced for smokers than for non-smokers (fig 3). By contrast, differences in PEF were more pronounced in nonsmokers $(-741 / \mathrm{min}, \mathrm{p}<0.001)$ than in smokers $(-41$ $1 / \mathrm{min}, \mathrm{p}<0.05$ ). Symptom prevalences were generally significantly higher in smokers than in non-smokers in the exposed group and the same trend was observed without reaching statistical significance in the controls. Differences in PEF between smokers and nonsmokers were non-significant in both groups.

Figure 4 shows the data when the exposed subjects were classified according to their working area. A clear gradient in symptom prevalence and in PEF values is observed from high to low dust exposure, with workers at the early stages of cotton processing (opening the bales, cleaning, and carding up to the spinning) having the highest symptom prevalences and the lowest PEF values and the few subjects from the quality control and storing area having results identical to those from the control group. The differences between the various groups are not accompanied by differences in age, height, smoking prevalences, or duration of 

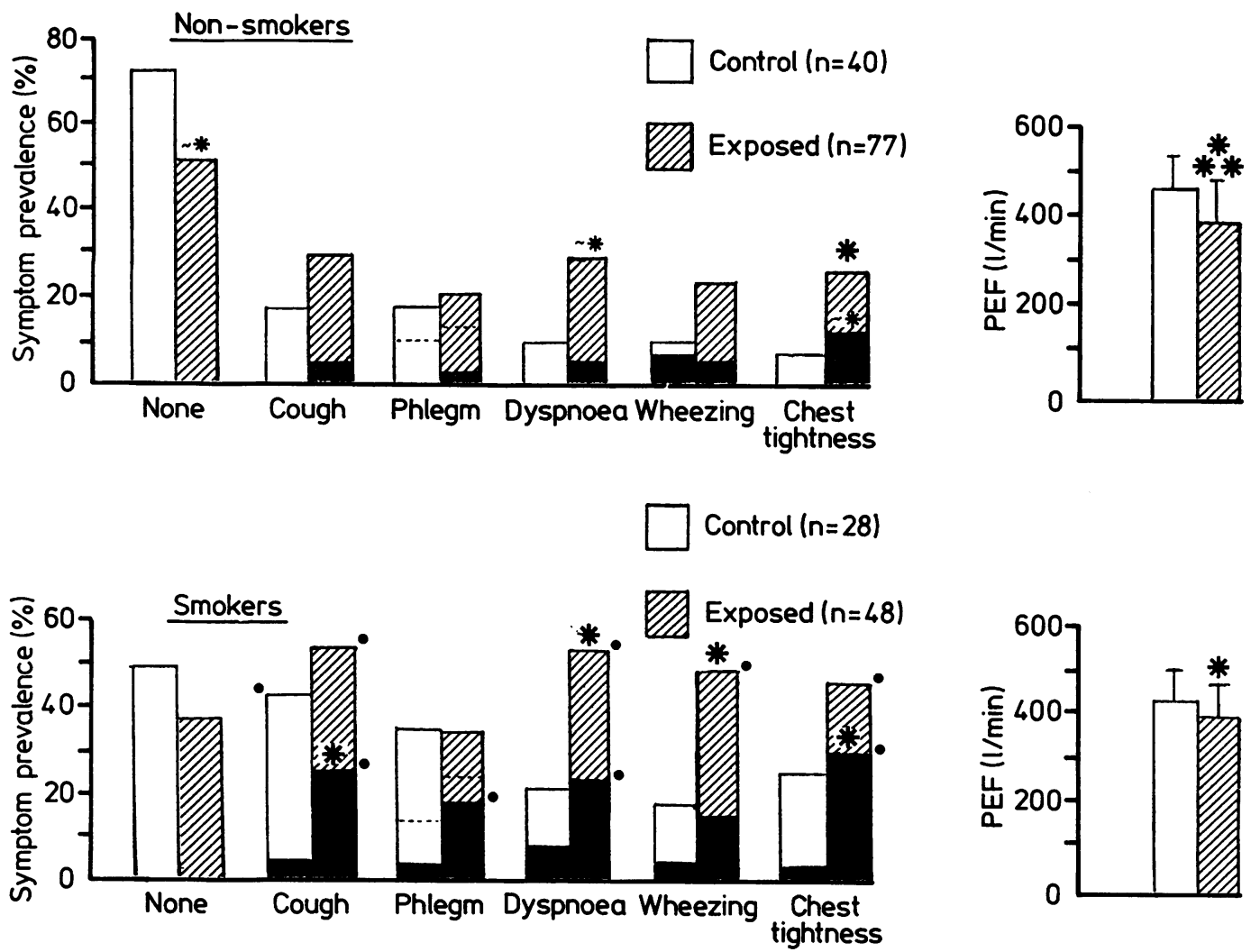

Specially first day of week

Fig 3 Symptom prevalences and PEF values (mean $\pm S D$ ) in control and exposed non-smokers or smokers. Interrupted lines in phlegm bars indicate prevalence of chronic bronchitis. For $P E F, n$ is slightly less than indicated. ${ }^{*} p \approx 0.05$, ${ }^{*} p<0.05,{ }^{* *} p<0.01,{ }^{* *} p<0.001$ for exposed $v$ control. $\bullet p<0.05$ for smokers $v$ non-smokers.

employment (not shown), but the workers from the first group weighed significantly less than the others $(64.2 \pm 7.9 \mathrm{~kg}, \mathrm{p}<0.05)$.

As shown in table 2, the exposed subjects reporting chest tightness, particularly those having this symptom after their weekly break, were older, had been employed longer, and were more often smokers than those without chest tightness. They also had significantly lower PEF values and significantly more chronic bronchitis.

There were no differences in sleep related symptoms between the exposed and control subjects $(32 \%$ and $28 \%$ of habitual snorers). Table 3 , however, presents the data relative to sleep related symptoms in the 23 subjects with byssinosis, defined as chest tightness occurring at the beginning of the working week, as compared with all other subjects. More subjects with byssinosis tended to report snoring (48\%), early morning headache $(48 \%)$, and sleep improvement over the working week (44\%) than among all other subjects $(28 \%, 24 \%$, and $24 \%$ respectively). There were no significant differences in weight, marital state, and drinking habits between the two groups but subjects with byssinosis were older and included more smokers.

\section{Discussion}

As expected ${ }^{126}$ total dust concentrations were highest in the first stages of the cotton processing, where the bales of cotton are opened up to the spinning stage, and they then decrease along the production line until the weaving stage. With hindsight the small group of seven subjects employed beyond the weaving department should have been included in the control group. On the other hand, the dust concentrations measured 

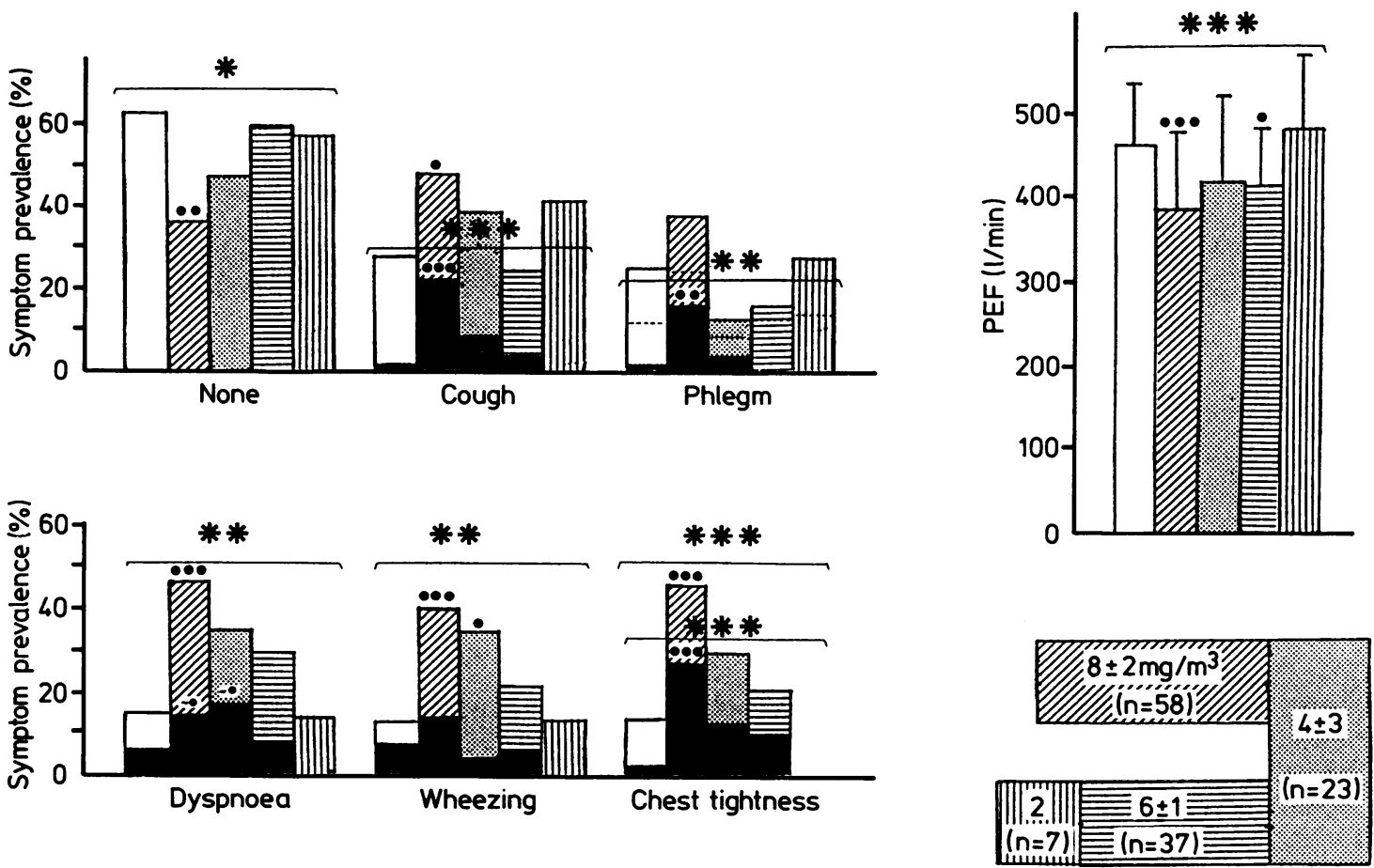

Specially first day of week

Control $2 \pm 1(n=68)$

Fig 4 Symptom prevalences and PEF values (mean $\pm S D$ ) in workers according to their work area. Scheme (bottom right) corresponds to that of fig 1 with mean $( \pm S D)$ dust concentrations and numbers of workers in each area. Interrupted lines in phlegm bars indicate prevalence of chronic bronchitis. For PEF, $n$ is slightly less than indicated. ${ }^{*} p<0.05,{ }^{* *} p<0.01$, ${ }_{* * *} p<0.001$ for overall differences between groups ( $\chi^{2}$ with 4 df or $F$ with 4 and $149 d f$ ). $\bullet p<0.05, \bullet \bullet p<0.01$, $\bullet \bullet \bullet p<0.001$ for difference of one group $v$ control.

outside the production areas were rather high and show that the control subjects were not entirely free from dust exposure. We do not know whether the relatively high dust concentrations in "control" areas resulted from the dusty atmosphere of the plant as a whole. Neither do we know from this preliminary study how much of the total dust collected was made up of the more relevant respirable or lint free cotton dust. A more detailed environmental dust measuring programme using a vertical elutriator would be required to resolve these issues. In any case the most urgent action consists in reducing the dust concentrations where they are highest.

If we take into account the most typical symptom, chest tightness occurring mainly after the weekly break, the prevalence of byssinosis among the production workers of the plant studied may be estimated to be around $18 \%$ ( 23 of 125 subjects). (The 19 production workers (and also nine control workers) who also reported chest tightness, but without a clear temporal

Table 2 Selected characteristics of exposed subjects with and without chest tightness

\begin{tabular}{|c|c|c|c|}
\hline & $\begin{array}{l}\text { No chest tightness } \\
(n=83)\end{array}$ & $\begin{array}{l}\text { Chest tightness } \\
(n=42)\end{array}$ & $\begin{array}{l}\text { Chest tightness 1st day of week } \\
(n=23) \ddagger\end{array}$ \\
\hline $\begin{array}{l}\text { Age (y) } \\
\text { Employment (y) } \\
\text { Smokers } \\
\text { Chronic bronchitis } \\
\text { PEF (l/min) }\end{array}$ & $\begin{array}{c}32 \cdot 7 \pm 5 \cdot 3 \dagger \\
10 \cdot 6 \pm 4 \cdot 4 \\
26(31 \cdot 3 \%) \\
5(6 \cdot 0 \%) \\
426 \pm 95(n=63)\end{array}$ & $\begin{array}{l}35 \cdot 1 \pm 4 \cdot 9 * * \\
12 \cdot 7 \pm 4 \cdot 1^{* *} \\
22(52 \cdot 4 \%)^{*} \\
17(40 \cdot 5 \%)^{* * *} \\
378 \pm 62 *(n=38)\end{array}$ & $\begin{array}{l}35 \cdot 9 \pm 4 \cdot 5^{* *} \\
12 \cdot 7 \pm 4 \cdot 7^{*} \\
14(60 \cdot 9 \%)^{*} \\
12(52 \cdot 2 \%)^{* * *} \\
356 \pm 50 *(n=22)\end{array}$ \\
\hline
\end{tabular}

${ }^{*} \mathrm{p}<0.05 ; *{ }^{*} \mathrm{p}<0.01 ; * * \mathrm{p}<0.001$ for difference $v$ subjects without chest tightness.

+ Mean \pm SD.

$\ddagger$ Data from these subjects are included in those from column 2. 
Table 3 General characteristics and sleep related symptoms in subjects with or without byssinosis

\begin{tabular}{|c|c|c|}
\hline & $\begin{array}{l}\text { Exposed subjects without byssinosis } \\
+ \text { control subjects }(n=170)\end{array}$ & $\begin{array}{l}\text { Exposed subjects with byssinosis } \\
(n=23)\end{array}$ \\
\hline $\begin{array}{l}\text { Age (y) } \\
\text { Weight (kg) } \\
\text { Single } \\
\text { Smokers } \\
\text { Pack years } \\
\text { Alcohol drinkers } \\
\text { Drinks/day } \\
\text { Snoring } \\
\text { Early morning headache } \\
\text { Daytime sleepiness } \\
\text { Restless sleep } \\
\text { Sleep improvement over working }\end{array}$ & $\begin{array}{c}33 \cdot 2 \pm 5 \cdot 9 \dagger \\
67 \cdot 1 \pm 7 \cdot 2(n=162) \\
27(15 \cdot 9 \%) \\
62(36 \cdot 5 \%) \\
11 \pm 7 \\
100(58 \cdot 8 \%) \\
3 \cdot 1 \pm 1 \cdot 7 \\
48(28 \cdot 2 \%) \\
41(24 \cdot 1 \%) \\
39(22 \cdot 9 \%) \\
37(21 \cdot 8 \%)\end{array}$ & $\begin{array}{l}35.9 \pm 4 \cdot 5 * \\
65 \cdot 0 \pm 6 \cdot 5(\mathrm{n}=21) \\
2(8 \cdot 7 \%) \\
14(60.9 \%)^{*} \\
14 \pm 8 \\
17(73.9 \%) \\
3.4 \pm 1.5 \\
11(47 \cdot 8 \%) \mathrm{p}<0.1 \\
11(47 \cdot 8 \%)^{*} \\
9(39 \cdot 1 \%) \\
8(34.8 \%)\end{array}$ \\
\hline week & $41(24 \cdot 1 \%)$ & $10(43.5 \%) p<0.1$ \\
\hline
\end{tabular}

* $<<0.05$. † Mean \pm SD.

pattern, were not considered to have byssinosis.) In agreement with published reports ${ }^{12-14}$ the prevalence of byssinosis was highest in the areas with the highest dust concentrations: thus $70 \%$ of the subjects with byssinosis came from the opening carding spinning department, giving a byssinosis prevalence of $28 \%$ (16 of 58 subjects) in that area. These prevalence figures may well underestimate the reality since more severely affected workers are likely to leave the factory because of respiratory disease, which anecdotal evidence suggests is often simply labelled as tuberculosis (cf ref 15).

Our results are in further agreement with most cited studies in that byssinosis and other respiratory symptoms were more frequent in smoking than nonsmoking subjects. This study is yet more evidence for the spread of the tobacco epidemic over the developing countries. ${ }^{16}$ The functional consequences of smoking are not pronounced in this study, presumably because of the relatively young age of the subjects and also because of the use of a rather insensitive index such as the PEF for measuring smoking induced airflow obstruction. ${ }^{17}$ It is, however, remarkable that on a group basis the PEF, measured with a miniature device, was able to discriminate extremely efficiently between exposed and control subjects on the one hand, and between affected and non-affected subjects on the other. The values obtained here are not necessarily "baseline" values since lung function was measured at the end of the working day. Some PEF values could therefore reflect acute bronchoconstrictor effects rather than the chronic effects of exposure to cotton dust. A preshift $v$ postshift study on Monday mornings and the inclusion of a group of truly unexposed control subjects would be necessary to distinguish acute and more long term functional effects.

It should be noted that, even in non-affected subjects, the values of PEF were lower than those expected on the basis of, for example, the EEC theoretical values. ${ }^{18}$ Thus using the data from all the asymptomatic subjects (whether exposed or control and whether non-smokers or smokers) the following regression equation was obtained:

$$
\begin{aligned}
\operatorname{PEF}(1 / \mathrm{min})= & 4.417 \times \text { height }(\mathrm{cm})-5.024 \text { age }(\mathrm{y})-137.3 \\
& (\mathrm{r}=0.45, \mathrm{n}=76, \mathrm{p}<0.01) .
\end{aligned}
$$

This equation gives PEF values that are only $80 \%$ of those of the EEC. ${ }^{18}$ This is probably attributable to ethnic differences. ${ }^{19} 20$

The inclusion of questions on sleep may appear surprising in a study of byssinosis. The background to this is the demonstration of an increase in apnoea index during sleep in patients with seasonal allergic rhinitis during the pollen season ${ }^{21}$ and the publication of an interesting case of clinically significant obstructive sleep apnoea caused by occupational sensitisation to guar gum dust. ${ }^{22}$ Whereas the exact pathogenic mechanism of byssinosis is still unclear, particularly with regard to the role of allergic mechanisms, and although nasal obstruction does not feature in descriptions of byssinosis symptoms, it was thought worth while to explore in a relatively large and homogeneous group of subjects whether an asthmatic disorder, such as byssinosis, might be associated with respiratory disturbances during sleep.

In this context the most easily studied of symptoms is snoring, which is considered to be a sensitive (though unspecific) marker for obstructive sleep apnoea. ${ }^{23}$ Our results do not permit any firm conclusion. There was a trend for the 23 subjects with typical symptoms of byssinosis to report more snoring and poorer quality of sleep, but this was not significant at the $5 \%$ level, and the differences found could be due to age and smoking habits, although other potential confounding factors appeared to be similar. ${ }^{23} 24$ The response rate for snoring in this study may seem rather high, but the prevalences of snoring have varied from $9 \%$ to $86 \%$ in men from other populations. ${ }^{23-26}$ Validation of questionnaires are certainly needed for this symptom. Despite the inconclusiveness of our present results relative to sleep, we believe that a more 
careful consideration of the effects of cotton dust, and also of other occupational exposures, on respiration during sleep is warranted. It has been shown that snoring is associated, by mechanisms that are not entirely clear, with a higher risk of dying from ischaemic heart disease or stroke. ${ }^{26}$ Occupational factors have so far received little attention in this research area.

The present survey, the first of its type in Cameroon and one of the few in tropical Africa, has shown that byssinosis exists in the cotton processing plant studied and that dust concentrations should therefore be reduced in this plant. An important aspect of our study is that this conclusion has been obtained on the basis of a survey carried out only with a questionnaire and minimal equipment - one air sampling pump and one cheap (less than US \$40) miniature peak flow measuring device.

We thank the management of the Cotonnière Industrielle du Cameroun (CICAM) of Garoua, Cameroon, for allowing us to conduct this survey, the staff for their help, and the workers for their participation. We thank Professor R Lauwerys, Dr J-P Buchet, and $\mathrm{Mr} \mathrm{J}-\mathrm{M}$ Defeld for their help and advice, Professor K Van de Woestijne for critical reading of the manuscript, and Ms V De Keyser for typing it. The financial support of the Belgian Government Agency for Development Cooperation (AGCD) is gratefully acknowledged.

\section{References}

1 Schilling RSF. Byssinosis. In: Parmeggiani L, ed. Encyclopaedia of occupational health and safety. 3rd ed. Geneva: International Labour Office, 1983:351-3.

2 Kilburn KH. Byssinosis and other diseases among textile workers. In: Rom WN, ed. Environmental and occupational medicine. Boston: Little, Brown \& Co, 1983:207-14.

3 Rylander R. Bacteria as etiological agents in byssinosis and other lung disease. Eur J Respir Dis 1982;63(suppl 123):34-46.

4 Kennedy SM, Christiani DC, Eisen EA, et al. Cotton dust and endotoxin exposure-response relationships in cotton textile workers. Am Rev Respir Dis 1987;135:194-200.

5 Connolly CK. Falsely high peak expiratory flow readings due to acceleration in the mouth. $\mathrm{Br}$ Med J 1987;294:285.

6 Quinn AE. Textile industry. In: Parmeggiani L, ed. Encyclopaedia of occupational health and safety. 3rd ed. Geneva: International Labour Office, 1983:2167-70.
7 Bouhuys A, Wolfson RL, Horner DW, Brain JD, Zuskin E. Byssinosis in cotton textile workers. Respiratory survey of a mill with rapid labor turnover. Ann Intern Med 1969;71:257-69.

8 Molyneux MKB, Tombleson JBL. An epidemiological study of respiratory symptoms in Lancashire mills, 1963-6. Br J Ind Med 1970;27:225-34.

9 Fox AJ, Tombleson JBL, Watt A, Wilkie AG. A survey of respiratory disease in cotton operators. Part II. Symptoms, dust estimations, and the effect of smoking habit. $\mathrm{Br} \mathrm{J}$ Ind $\mathrm{Med}$ 1973;30:48-53.

10 Berry G, Molyneux MKB, Tombleson JBL. Relationship between dust level and byssinosis and bronchitis in Lancashire cotton mills. Br J Ind Med 1974;31:18-27.

11 Merchant JA, Kilburn KH, O'Fallon WM, Hamilton JD, Lumsden JC. Byssinosis and chronic bronchitis among cotton textile workers. Ann Intern Med 1972;76:423-33.

12 Merchant JA, Lumsden JC, Kilburn KH, et al. Dose response studies in cotton textile workers. J Occup Med 1973;15:222-30.

13 Jones RN, Diem JE, Glindmeyer M, et al. Mill effect and dose-response relationship in byssinosis. $\mathrm{Br} \mathrm{J}$ Ind $\mathrm{Med}$ 1979;36: 305-13.

14 Noweir MH, Noweir KH, Osman HA, Moselhi M. An environmental and medical study of byssinosis and other respiratory conditions in the cotton textile industry in Egypt. Am J Ind Med 1984;6:173-84.

15 Christiani DC, Eisen EA, Wegman DK, et al. Respiratory disease in cotton textile workers. I. Respiratory symptoms. Scand J Work Environ Health 1986;12:40-4.

16 Anonymous. Third world smoking. The new slave trade. Lancet 1984;i:23-4.

17 Nemery B, Moavero NE, Brasseur L, Stanescu D. Significance of small airway tests in middle-aged smokers. Am Rev Respir Dis 1981;124:232-8.

18 Quanjer PH. Standardized lung function testing. Bull Eur Physiopathol Respir 1983;19(suppl 5).

19 Elebute EA, Pearse F. Peak flow rate in Nigeria. Anthropometric determinants and usefulness in assessment of ventilatory function. Thorax 1971;26:597-601.

20 Mustafa KY. Spirometric lung function tests in normal men of African ethnic origin. Am Rev Respir Dis 1977;116:209-13.

21 McNicholas WT, Tarlo S, Cole P, et al. Obstructive apneas during sleep in patients with seasonal allergic rhinitis. Am Rev Respir Dis 1982;126:625-8.

22 Leznoff A, Haight JS, Hoffstein V. Reversible obstructive sleep apnea caused by occupational exposure to guar gum dust. Am Rev Respir Dis 86;133:935-6.

23 Lugaresi E, Cirignotta F, Coccagna G, Piana C. Some epidemiological data on snoring and cardiocirculatory disturbances. Sleep 1980;3:221-4.

24 Koskenvuo M, Kaprio J, Partinen M, Langinvainio M, Sarno S, Heikkilä K. Snoring as a risk factor for hypertension and angina pectoris. Lancet 1985;i:893-6.

25 Norton PG, Dunn EV, Haight JS. Snoring in adults: some epidemiologic aspects. Can Med Assoc J 1983;128:674-5.

26 Koskenvuo M, Kaprio J, Telakivi T, Partinen M, Heikkilä K, Sarna S. Snoring as a risk factor for ischaemic heart disease and stroke in men. Br Med J 1987;294:16-9. 